\title{
Interactive comment on "Continuous
} measurements of nitrous oxide isotopomers \section{during incubation experiments" by Malte Winther} \section{et al.}

\section{Anonymous Referee \#1}

Received and published: 8 July 2016

The comment was uploaded in the form of a supplement:

http://www.biogeosciences-discuss.net/bg-2016-258/bg-2016-258-RC1-

supplement.pdf

Interactive comment on Biogeosciences Discuss., doi:10.5194/bg-2016-258, 2016. 